\title{
PENERAPAN PERMAINAN KARET TERHADAP MINAT SISWA DALAM PEMBELAJARAN LARI JARAK PENDEK KELAS VII SMP NEGERI 1 BELIMBING HULU
}

\author{
Fajarino $^{1}$, Nur Moh Kusuma Atmaja ${ }^{2}$, Suyatmin ${ }^{3}$, \\ ${ }^{1}$ Mahasiswa Program Studi Penjaskesrek \\ ${ }^{2,3}$ Dosen STKIP Melawi
}

Jl. RSUD Melawi km. 04 Kec. Nanga Pinoh Kab. Melawi Kalimantan Barat

Email: fajarinofajar@gmail.com, atmajanur27@gmail.com, suyatminuny@gmail.com

\begin{abstract}
Abstrack: This research starts from the low interest of students in sports and learning that is done directly the core material. This study aims to increase the interest of class VII Junior Hight School 1th Belimbing Hulu State. This research is a classroom action research. The subjects of the study were of class Junior Hight School 1th Belimbing Hulu State, amounting to 41 people consisting of 21 male students and 20 famale students, with an object of 20 students consisting of 11 male students and 9 female students. For the date collection model used in this study is to use an obsevation guide sheet or a questionnaire conducted by the teacher or reseacher. The results that through a gamewith rumbber aids can increase sudents interest in learning to run short distances in class VII Junior Hight School 1th Belimbing Hulu State, based on obsevation, there was an increase in the average value of cycles I and II (22,5\%).
\end{abstract}

\section{Keywords : Application Of Games, Students Interest.}

Abstrak: Penelitian ini berawal dari masih rendahnya minat siswa dalam berolahraga, dan pembelajaran yang dilakukan langsung masuk kemateri inti. Penelitian ini bertujuan untuk meningkatkan minat siswa dalam pembelajaran lari jarak pendek melalui permainan dengan alat bantu karet pada siswa kelas VII SMP Negeri 1 Belimbing Hulu. Penelitian ini merupakan penelitian tindakan kelas. Subjek penelitian adalah siswa kelas VII SMP Negeri 1 Belimbing Hulu yang berjumlah 41 orang yang terdiri dari 21 siswa laki-laki dan 20 siswa perempuan, dengan objek 20 siswa yang terdiri dari 11 siswa laki-laki dan 9 siswa perempuan. Untuk model pengumpulan data yang digunakan dalam penelitian ini adalah menggunakan lembar pedoman observasi atau angket yang dilakukan oleh guru atau peneliti. Hasil penelitian menunjukkan bahwa melalui permainan dengan alat bantu karet dapat meningkatkan minat siswa dalam pembelajarann lari jarak pendek pada siswa kelas VII SMP Negeri 1 Belimbing Hulu, berdasarkan hasil observasi, terlihat adanya peningkatan nilai rata-rata dari siklus I dan II $(22,5 \%)$.

Kata Kunci : Penerapan Permainan Karet, Minat Siswa 
$\mathrm{p}$ endidikan adalah usaha sadar dan terencana untuk mewujudkan suasana belajar dan proses pembelajaran untuk peserta didik agar secara aktif keagamaan, pegadilan diri, kepribadian, kecerdasan, ahlak mulia, serta keterampilan yang diperlukan dirinya dan masyarakat. Pendidikan mengembangkan karakter melalui berbagai macam kegiatan seperti penanaman nilai, pengembangan budi pekerti, nilai agama, pembelajaran dan pelatihan nilai-nilai moral, dan yang lain sebagainya.

Pendidikan jasmani adalah salah mata pelajaran di sekolah yang merupakan media pendorong perkembangan keterampilan motorik, kemampuan fisik, pengetahuan, sikap sportifitas, pembiasaan pola hidup sehat dan pembentukan karakter (mental, emosional, spiritual dan sosial) dalam rangka mencapai tujuan sistem pendidikan Nasional. Undang-undang Nomor 20 Tahun 2003 tentang sisdiknas, Pembelajaran adalah proses intraksi peserta didik dengan pendidik dan sumber belajar pada suatu lingkungan belajar.

Menurut Briggs (1977:87) media pembelajaran adalah sarana fisik untuk menyampaikan isi atau materi pembelajaran seperti: buku, film, vidio, dan sebagainya. Kemudian menurut National Education Association (1969) mengungkapkan bahwa media pembelajaran sarana komunikasi dalam bentuk cetak maupun pandangdengar, termasuk teknologi perangkat keras.

Berdasarkan hasil observasi yang dilakukan oleh penulis, yang dilaksankan pada tanggal 25-27 Juli 2019 tepatnya di SMP Negeri 1 Belimbing Hulu dengan wawancara kepada salah satu guru penjasorkes dan juga observasi langsung untuk mengetahui proses belajar mengajar pendidikan jasmani khususnya pembelajaran atletik, serta permasalahan apa saja yang dihadapi saat pembelajaran atletik, dan dapat di temukan beberapa data sebagai berikut: (1) Kurangnya sarana dan prasarana olahraga atletik di SMP Negeri 1 Belimbing Hulu yang kurang memadai. (2) yang dilakukan langsung masuk kemateri inti. (3) Pada pembelajaran atletik banyak siswa yang terlihat bosan dan kurang bersemangat dalam pembelajaran di kerenakan belum di kemas kedalam permainan modifikasi. (4) Ada beberapa siswa yang tidak mengikuti oahraga dan asik bermain sendiri. (5) Ada beberapa juga siswa kelas VII yang tidak mengikuti olahraga melihat ke kelas lain yang sedang belajar pada saat jam olahraga.

(6) Kurangnya minat siswa dalam berolahraga. Berdasarkan permasalahanpermasalahan tersebut, maka dipandang penting adanya pengembangan model permaminan penjasorkes yang perlu dilakukan di SMP Negeri 1 Belimbing Hulu, oleh kerena itu perlu dibuat sebuah model permainan atletik yang cocok untuk 
pembelajaran sisawa SMP. Peneliti akan mengembagkan hasil modifikasi permainan menarik karet menggunakan ban dalam bekas motor yang semua aktivitas geraknya sangat erat kaitannya dengan semua komponen-komponen ranah yang terkandung dalam penjasorkes yaitu ranah kognitif, ranah afektif, dan ranah psikomotorik.

Tujuan penelitian ini adalah untuk meningkatkan minat siswa dalam pembelajaran atletik khususnya lari jarak pendek dalam pembelajaran penjasokes melalui modifikasi permainan yaitu

"Penerapan Permainan Karet terhadap minat siswa Dalam Pembelajaran Lari Jarak Pendek Kelas VII SMP Negeri 1 Belimbing Hulu" sehingga dapat mengembangkan berbagai aspek pembelajaran dan dapat meningkatkan aktivitas fisik dalam pembelajaran penjasorkes.

\section{METODE PENELITIAN}

Desain yang digunakan dalam penelitian ini adalah Penelitian Tindakan Kelas dengan menggunakan siklus. Menurut Agus Kristiyato (2010:18), tujuan Penelitian Tindakan Kelas adalah untuk memperoleh cara meningkatkan atau memanifulasi perlakuan atau tindakan dalam pembelajaran pendidikan jasmani agar proses dan hasil pembelajaran pendidikan jasmani meningkat. Ada empat tahap pentingdalam penelitian tindakan kelas yaitu perencanaa (planning), tindakan (action), pengamatan (observing), dan refleksi (reflecting).

\section{Subjek dan Objek}

Subjek Penelitian Tindakan Kelas ini adalah seluruh siswa kelas VII SMP Negeri 1 Belimbing Hulu, yang berjumlah 20 jumlah orang yang terdiri dari 11 orang lakilaki dan 9 orang perempuan.

Objek Penelitian Tindakan Kelas ini adalah minat siswa kelas VII SMP Negeri 1 Belimbing Hulu.

\section{Teknik Pengumpulan Data}

Menurut Riduwan

(2015:76) mengemukakan "Observasi yaitu melakukan pengamatan secara langsung kepada objek penelitian untuk melihat dari dekat kegiatan yang dilakukan”. Sedangkan menurut Zuriah (2009:173) mengemukakan “Observasi yang dilakukan di mana observer berada bersama objek yang diselidiki". Teknik observasi langsung digunakan untuk mengetahui bagaimana kegiatan pada saat proses pembelajaran berlangsung baik itu kegiatan guru maupun kegiatan siswa.

\section{Instrumen Penelitian}

Dalam penelitian ini penulis menggunakan instrumen tes untuk meningkatkan kemampuan lari jarak pendek siswa (tes akselerasi 30 meter) untuk mengetahui kemanpuan lari dengan cepat dan mengetahui kecepata seorang siswa. Intrumen dalam penelitian ini menggunakan lembar pedoman observasi untuk mengamati proses pembelajaran. Lembar observasi 
digunakan oleh guru dan kolaborator untuk melakukan observasi secara langsung. Pengamatan di arahkan pada gerak lari.

Tabel 3.1 Angket Minat Belajar Siswa

\begin{tabular}{|c|c|c|c|}
\hline \multirow[b]{2}{*}{ No } & \multirow[b]{2}{*}{ Pernyataan } & \multicolumn{2}{|c|}{ Jawaban } \\
\hline & & $\mathbf{Y a}$ & Tidak \\
\hline 1 & $\begin{array}{l}\text { Saya tertarik pada } \\
\text { pembelajaran atletik } \\
\text { khususnya lari jarak } \\
\text { pendek. }\end{array}$ & & \\
\hline 2 & $\begin{array}{l}\text { Saya antusias dan } \\
\text { semangat } \\
\text { pembelajaran atletik } \\
\text { berlangsung. }\end{array}$ & & \\
\hline 3 & $\begin{array}{l}\text { Saya sangat senang } \\
\text { mendiskusikan } \\
\text { pembelajaran lari jarak } \\
\text { pendek saat } \\
\text { pembelajaran. }\end{array}$ & & \\
\hline 4 & $\begin{array}{lr}\text { Saya } & \text { sering } \\
\text { mengajukan } & \\
\text { pertanyaan } & \text { dan } \\
\text { pendapat } & \text { dalam } \\
\text { pembelaran di kelas. }\end{array}$ & & \\
\hline 5 & $\begin{array}{l}\text { Saya suka menyimak } \\
\text { dan fokus pada materi } \\
\text { pembelajaran lari jarak } \\
\text { pendek yang di } \\
\text { sampaikan. }\end{array}$ & & \\
\hline 6 & $\begin{array}{lr}\text { Saya } & \text { suka } \\
\text { pembelajaran atletik } \\
\text { khususnya lari jarak } \\
\text { pendek. }\end{array}$ & & \\
\hline 7 & $\begin{array}{lr}\text { Saya } & \text { suka } \\
\text { mendefinisikan } & \text { lari } \\
\text { jarak pendek. } & \end{array}$ & & \\
\hline 8 & $\begin{array}{l}\text { Saya pada saat praktek } \\
\text { saya selau serius. }\end{array}$ & & \\
\hline 9 & Saya sangat malu saat & & \\
\hline
\end{tabular}

\begin{tabular}{|l|l|l|l|}
\hline & $\begin{array}{l}\text { memprakterkkan lari } \\
\text { jarak pendek. }\end{array}$ & & \\
\hline 10 & $\begin{array}{l}\text { Nilai yang saya } \\
\text { dapatkan selalu tuntas } \\
\text { di atas KKM. }\end{array}$ & & \\
\hline Skor maksimal & & \\
\hline
\end{tabular}

\section{Teknik Analisis Data dan Kriteria}

\section{Keberhasilan}

Untuk menentukan penilaian sikap perhitungan skor akhir menggunakan rumus: $\frac{\text { skor prolehan }}{\text { skor max }}$ x $100=$ skor akhir. Setelah didapat prolehan skor akhir kemudian dikonversi kedalam tabel penilaian unjuk kerja dan prilaku siswa.

Indikator keberhasilan pada penelitian tindakan kelas ini adanya peningkatan hasil dari proses belajar yang meliputi meningkatnya minat siswa dalam pembelajaran lari jarak pendek yang meliputi star, lari, dan finish. dengan menggunakan permainan karet.Kriteria keberhasilan apabila prolehan nilai siswa secara individual sudah lebih dari $75 \%$ dari jumlah siswa memperoleh nilai di atas Kriteria Ketuntasan Minimal(KKM) yaitu 75 .

Tabel 3.4 Daftar Konversi Untuk Penilaian Unjuk Kerja dan Prilaku Siswa

Interval Kriteria
Nilai

$\begin{array}{cc}86-100 & \text { Baik Sekali } \\ 75-85 & \text { Baik }\end{array}$




\begin{tabular}{cc}
$65-74$ & Sedang \\
$55-64$ & Kurang \\
$<55$ & Kurang Sekali \\
\hline
\end{tabular}

\section{HASIL DAN PEMBAHASAN}

Penelitian dilaksanakan sebanyak dua siklus yang dilakukan pada tanggal 8 dan 15 Februari 2020. Semua siswa dapat mengikuti proses pembelajaran pada pelaksanaan tindakan kelas siklus pertama dan kedua.

Siklus pertaman dilaksanakan selama satu kali pertemuan yaitu dengan materi pokok lari jarak pendek yang di bahas pada pertemuan ini adalah meningkatkan minat siswa. Siklus pertama yang dilaksanakan satu kali pertemuan ini, di hadiri 20 siswa. Kriteria keberhasilan apabila prolehan nilai siswa secara individual sudah lebih dari $75 \%$ dari jumlah siswa memperoleh nilai diatas nilai Kriteria Ketuntasan Minimal (KKM) 75.

Tabel 4.1 Rekapitulasi penilaian Minat siswa siklus I

\begin{tabular}{cccccc}
\hline No & Na & Sk & Sk & Nil & Ketera \\
& ma & or & or & ai & nga \\
& & Pe & M & & \\
& & & \\
& & \\
& eh & ak & & & \\
& & si & & \\
& & an & ma & & \\
& & & 1 & & \\
\hline 1 & AF & 7 & 10 & 70 & Sedang \\
2 & A & 5 & 10 & 50 & Kuran \\
& V & & & & g \\
3 & E & 6 & 10 & 60 & Sedang \\
4 & FA & 4 & 10 & 40 & $\begin{array}{c}\text { Kuran } \\
\text { g } \\
\text { sekali }\end{array}$ \\
& & & & &
\end{tabular}

\begin{tabular}{|c|c|c|c|c|c|}
\hline 5 & FA & 6 & 10 & 60 & $\begin{array}{c}\text { Kuran } \\
\mathrm{g}\end{array}$ \\
\hline 6 & FY & 6 & 10 & 60 & $\begin{array}{c}\text { Kuran } \\
\mathrm{g}\end{array}$ \\
\hline 7 & $\mathrm{HF}$ & 7 & 10 & 70 & Sedang \\
\hline 8 & $\begin{array}{l}\mathrm{M} \\
\mathrm{C}\end{array}$ & 6 & 10 & 60 & $\begin{array}{c}\text { Kuran } \\
\mathrm{g}\end{array}$ \\
\hline 9 & $\begin{array}{l}\mathrm{M} \\
\mathrm{P}\end{array}$ & 6 & 10 & 60 & $\begin{array}{c}\text { Kuran } \\
\mathrm{g}\end{array}$ \\
\hline 10 & $\mathrm{P}$ & 3 & 10 & 30 & $\begin{array}{c}\text { Kuran } \\
\mathrm{g} \\
\text { sekali }\end{array}$ \\
\hline 11 & $\mathrm{P}$ & 7 & 10 & 70 & Sedang \\
\hline 12 & $\begin{array}{l}\mathrm{R} \\
\mathrm{A}\end{array}$ & 7 & 10 & 70 & Sedang \\
\hline 13 & $\begin{array}{l}\mathrm{R} \\
\mathrm{H} \\
\mathrm{N}\end{array}$ & 7 & 10 & 70 & Sedang \\
\hline 14 & $\begin{array}{l}\mathrm{R} \\
\mathrm{A}\end{array}$ & 6 & 10 & 60 & $\begin{array}{c}\text { Kuran } \\
\mathrm{g}\end{array}$ \\
\hline 15 & RI & 6 & 10 & 60 & $\begin{array}{c}\text { Kuran } \\
\mathrm{g}\end{array}$ \\
\hline 16 & $\begin{array}{l}\mathrm{R} \\
\mathrm{SA}\end{array}$ & $\begin{array}{l}7 \\
8\end{array}$ & $\begin{array}{l}10 \\
10\end{array}$ & $\begin{array}{l}70 \\
80\end{array}$ & $\begin{array}{c}\text { Sedang } \\
\text { Baik }\end{array}$ \\
\hline $\begin{array}{l}17 \\
18\end{array}$ & $\begin{array}{l}\mathrm{S} \\
\mathrm{M}\end{array}$ & 6 & 10 & 60 & $\underset{\sigma}{\text { Kuran }}$ \\
\hline 19 & SA & 6 & 10 & 60 & $\underset{\mathrm{g}}{\text { Kuran }}$ \\
\hline 20 & $\mathrm{~S}$ & 5 & 10 & 50 & Kuran \\
\hline Juml & & $\begin{array}{c}12 \\
1\end{array}$ & & $\begin{array}{l}12 \\
10\end{array}$ & 20 \\
\hline $\begin{array}{l}\text { Rata } \\
\text { rata } \\
\text { Ketu } \\
\text { san }\end{array}$ & Inta & $\begin{array}{c}6,0 \\
5\end{array}$ & & $\begin{array}{c}60, \\
5\end{array}$ & $\begin{array}{c}\text { Kuran } \\
\mathrm{g} \\
\text { Belum } \\
\text { Tuntas }\end{array}$ \\
\hline
\end{tabular}


Berdasarkan tabel 4.1 diatas diuraikan bahwa hasil minat siswa, tidak ada siswa yang berkategori Baik Sekali (BS), sebanyak 2 siswa (10\%) dalam kategori Baik (B), sebanyak 6 siswa (30\%) dalam kategori Sedang (S), sebanyak 10 siswa (50\%) dalam katergori Kurang (K), dan sebanyak 2 siswa (10\%) dalam kategori Kurang Sekali (KS).

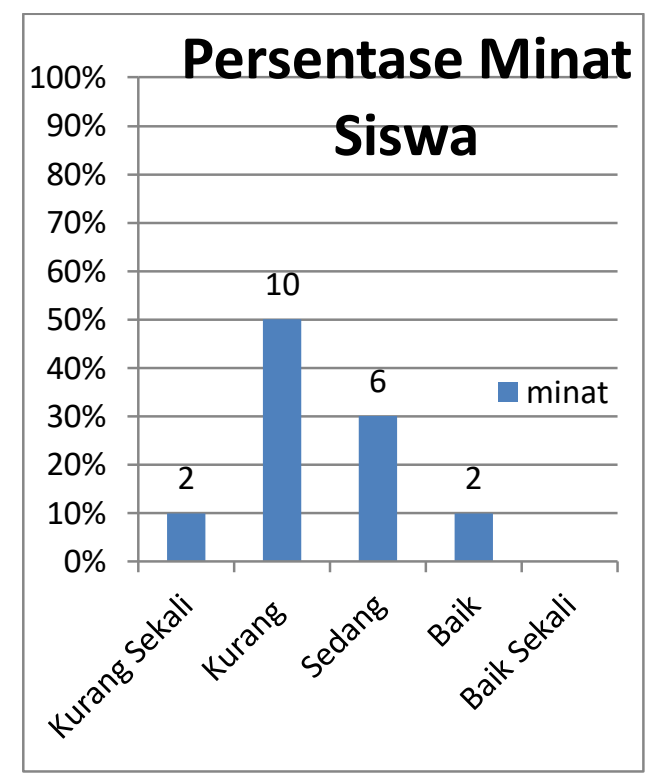

Gambar. 4.1 Grafik Histogram Hasil Minat Siswa Siklus I

Berdasarkan dari diagram gambar $4.1 \mathrm{di}$ atas kriteria ketuntasan siswa yaitu, sebanyak 2 siswa dinyatakan tuntas yaitu nilai yang diperoleh di atas (KKM) 75. Dengan prsentase (10\%) dan sebanyak 18 siswa dinyatakan belum tuntas, dengan persentase 6 siswa (30\%) dengan kategori Sedang (S), 2 siswa (10\%) berkategori Kurang (K), dan 10 siswa (50\%) dengan kategori Kurang Sekali (KS). Kerena siswa tersebebut belum mendapatkan nilai di atas (KKM) yaitu 75 .
Siklus kedua dilaksanakan pada tanggal 15 Februari 2020 dengan jumlah 20 siswa. Pada siklus II ini dan kriteria keberhasilan seperti yang diterapkan pada siklus I. Tindakan yang dilakukan pada siklus II ditetapkan berdasarkan hasil refleksi pada siklus I.

Tabel 4.3 Rekapitulasi penilaian siklus II

\begin{tabular}{|c|c|c|c|c|c|}
\hline No & $\begin{array}{l}\mathrm{Na} \\
\mathrm{ma}\end{array}$ & $\begin{array}{c}\text { Sk } \\
\text { or } \\
\text { Per } \\
\text { ole } \\
\text { ha } \\
\mathrm{n}\end{array}$ & $\begin{array}{c}\mathrm{Sk} \\
\text { or } \\
\mathrm{Ma} \\
\mathrm{ksi} \\
\mathrm{ma} \\
1\end{array}$ & $\begin{array}{c}\text { Nila } \\
\text { i }\end{array}$ & $\begin{array}{c}\text { Keter } \\
\text { anga }\end{array}$ \\
\hline 1 & $\mathrm{AF}$ & 8 & 10 & 80 & Baik \\
\hline 2 & $\begin{array}{l}\mathrm{A} \\
\mathrm{V}\end{array}$ & 9 & 10 & 90 & $\begin{array}{c}\text { Baik } \\
\text { Sekal } \\
\text { i }\end{array}$ \\
\hline 3 & E & 8 & 10 & 80 & Baik \\
\hline 4 & FA & 8 & 10 & 80 & Baik \\
\hline 5 & FA & 9 & 10 & 90 & $\begin{array}{c}\text { Baik } \\
\text { Sekal } \\
\text { i }\end{array}$ \\
\hline 6 & FY & 8 & 10 & 80 & Baik \\
\hline 7 & $\mathrm{HF}$ & 8 & 10 & 80 & Baik \\
\hline 8 & $\begin{array}{l}\mathrm{M} \\
\mathrm{C}\end{array}$ & 8 & 10 & 80 & Baik \\
\hline 9 & $\begin{array}{l}\mathrm{M} \\
\mathrm{P}\end{array}$ & 8 & 10 & 80 & Baik \\
\hline 10 & $\mathrm{P}$ & 8 & 10 & 80 & Baik \\
\hline 11 & $\mathrm{P}$ & 9 & 10 & 90 & $\begin{array}{c}\text { Baik } \\
\text { Sekal } \\
\text { i }\end{array}$ \\
\hline 12 & $\begin{array}{l}\mathrm{R} \\
\mathrm{A}\end{array}$ & 9 & 10 & 90 & $\begin{array}{c}\text { Baik } \\
\text { Sekal } \\
\text { i }\end{array}$ \\
\hline 13 & $\begin{array}{l}\mathrm{R} \\
\mathrm{H} \\
\mathrm{N}\end{array}$ & 8 & 10 & 80 & Baik \\
\hline 14 & $\begin{array}{l}\mathrm{R} \\
\mathrm{A}\end{array}$ & 8 & 10 & 80 & Baik \\
\hline 15 & RI & 8 & 10 & 80 & Baik \\
\hline 16 & $\mathrm{R}$ & 9 & 10 & 90 & $\begin{array}{c}\text { Baik } \\
\text { Sekal } \\
\text { i }\end{array}$ \\
\hline 17 & SA & 8 & 10 & 80 & Baik \\
\hline 18 & $\mathrm{~S}$ & 9 & 10 & 90 & Baik \\
\hline
\end{tabular}


M

Sekal

19 SA $\quad 8 \quad 10 \quad 80 \quad$ Baik

$\begin{array}{llllll}20 & \mathrm{~S} & 8 & 10 & 80 & \text { Baik }\end{array}$

$\begin{array}{llll}\text { Jumlah } & 16 & 166 & 20\end{array}$

$\begin{array}{lccc} & 6 & 0 & \\ \text { Rata- } & 8,3 & 83 & \text { Baik }\end{array}$

rata

Ketuntas

Tunta

an

Nilai $=\frac{\text { jumlah perolehan }}{\text { jumlah } \text { skor }} \times 100$

Berdasarkan dari tabel 4.3 diatas dapat diuraikan hasil dari minat siswa pada siklus II, 6 siswa (30\%) yang berkategori Baik Sekali (BS), sebanyak 14 siswa (70\%) dalam kategori Baik (B), $\mathrm{t}$ didak ada siswa dalam kategori Sedang (S), tidak ada siswa dalam kategori Kurang (K), dan tidak ada siswa dalam kategori Kurang Sekali (KS).

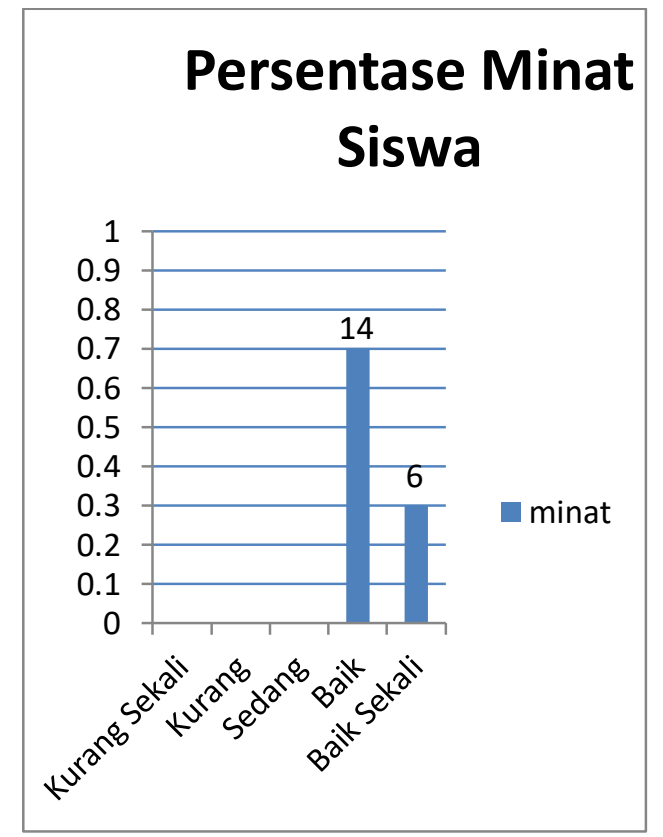

Gambar. 4.2 Grafik Histogram Hasil Minat Siswa Siklus II

Berdasarkan dari diagram gambar $4.2 \mathrm{di}$ atas yang diperoleh dari siklus II kriteria ketuntasan siswa yaitu sebanyak 20 siswa dinyatakan tuntas kerena nilai yang diperoleh oleh setiap siswa diatas (KKM) 75. Dengan persentase 6 siswa $(30 \%)$ dengan kategori Baik Sekali (BS), dan 14 siswa (70\%) berkatgori Baik (B).

Dijelaskan bahwa pada siklus pertama tidak ada siswa yang berkategori Baik Sekali (BS), sebanyak 2 siswa (10\%) dalam kategori Baik (B), sebanyak 6 siswa (30\%) dalam kategori Sedang (S), sebanyak 10 siswa (50\%) dalam katergori Kurang (K), dan sebanyak 2 siswa (10\%) dalam kategori Kurang Sekali (KS). Selanjutnya untuk siklus kedua 6 siswa (30\%) yang berkategori Baik Sekali (BS), sebanyak 14 siswa (70\%) dalam kategori Baik (B), tidak ada siswa dalam kategori Sedang (S), tidak ada siswa dalam kategori Kurang (K), dan tidak ada siswa dalam kategori Kurang Sekali (KS). Untuk peningkatan nilai rata-rata dari siklus pertama dan kedua adalah $(22,5 \%)$.

\section{KESIMPULAN}

Berdasar hasil analisis dan pembahasan yang telah diurai pada bab sebelumnya, maka kesimpulan yang dapat di ambil, sebagai berikut : Berdsasar hasil data dapat dijelaskan bahwa pada siklus pertama tidak ada siswa yang berkategori Baik Sekali (BS), sebanyak 2 siswa (10\%) dalam kategori Baik (B), sebanyak 6 siswa (30\%) dalam kategori Sedang (S), sebanyak 10 siswa $(50 \%)$ dalam katergori Kurang (K), dan sebanyak 2 siswa (10\%) dalam kategori Kurang Sekali (KS). Selanjutnya untuk 
siklus kedua 6 siswa (30\%) yang berkategori Baik Sekali (BS), sebanyak 14 siswa (70\%) dalam kategori Baik (B), tidak ada siswa dalam kategori Sedang (S), tidak ada siswa dalam kategori Kurang (K), dan tidak ada siswa dalam kategori Kurang Sekali (KS). Untuk peningkatan nilai rata-rata dari siklus pertama dan kedua adalah (22,5\%). pembelajaran melalui permainan karet dapat membantu meningkatkan minat siswa dalam pembelajaran. Mengenai penerapan permainan karet terhadap minat siswa dalam pembelajaran lari jarak pendek kelas VII SMP Negeri 1 Belimbing Hulu.

\section{DAFTAR PUSTAKA}

Agus Kristiyanto.2010. Penelitian Tindakan Kelas (PTK) Dalam Pendidikan Jasmani \& Kepelatihan Olahraga. Surakarta: UNS Press.

Briggs, Leslie J. 1977. Instructional Design,Educational Technology Publications Inc. New Jersey : Englewood Cliffs.

Depdiknas .2003. Undang-undang RI No.20 tahun 2003.tentang sistem pendidikan nasional.

2006. Permendiknas.No.22 tentang Tujuan Pendidikan Jasmani Olahraga dan Kesehatan.Jakarta: Depdiknas.

Riduwan. 2015. Belajar Mudah Penelitian
Penelitian Pemula. Bandung: Alfabeta. 